\title{
Analysis of the stages of development and evolution of the characteristics of logistics in Gwadar port under the Background of China-Pakistan Economic Corridor and the Belt and Road
}

\author{
Aimin Deng, Tiancheng Xu
}

\begin{abstract}
Port has always been an important node of "Belt and Road", a hub of global trade flow, and has a great influence on the development of regional economy. Gwadar Port, with its unique advantages, has become the land starting point of "China-Pakistan Economic Corridor" and an important connection point of "Belt and Road Maritime Silk Road". Different ports have different effects and influencing factors on the agglomeration and diffusion of port logistics due to different natural geography, socio-economic, political and legal aspects and development plans. This paper analyzes the development stages and evolution characteristics of Gwadar port logistics and its dynamic mechanism in the context of Belt and Road and China-Pakistan Economic Corridor development.
\end{abstract}

Index Terms — port development stage, port development evolution, Belt and Road, China-Pakistan Economic Corridor, logistics

\section{INTRODUCTION}

The year 2020 marks the seventh year of China's "One Belt, One Road" and the seventh year of the "China-Pakistan Economic Corridor (CPEC)" concept. The China-Pakistan Economic Corridor (CPEC) has been regarded as the flagship project and demonstration project of the Belt and Road, and the Gwadar Port is the highlight of China-Pakistan economic cooperation. In this context, both China and Pakistan have made detailed designs for the development of Gwadar Port, and in early August 2019, the Pakistani Cabinet officially approved the Gwadar Smart Port City Master Plan, which is a guiding document for the construction of Gwadar Port and the city, and the development of Gwadar Port has entered a new phase.

Although the port development and logistics system construction of Gwadar port is still in the primary stage so far, its port and port logistics development will show special development stages and development evolution characteristics due to its own special development planning background and geographical location. In this paper, we analyze the development stages and evolution characteristics of Gwadar Port in the context of Belt and Road and

Aimin Deng, Ph.D, Professor of School of Economics and Trade, Hunan University, Changsha, China

Tiancheng Xu, Master of School of Economics and Trade, Changsha, China
China-Pakistan Economic Corridor by combining the model of port development evolution and the analysis of dynamic reasons, in order to provide a reference for the future logistics development of Gwadar Port.

\section{LITERATURE REVIEW}

\section{A. The research of the stages and evolution of port development}

Ports have always played a leading, bridging and linking role in the development of global and regional economies. Therefore, from ancient times to the present, from the West to the East, the discussion of the stages of development and evolution of ports has been an important topic. Many scholars have discussed the development stages and evolution of ports from different perspectives, and have proposed and validated various theories of port development.

\section{Research on the development stages of the port \\ 1.1 Anyport Model}

Traditionally, ports are the convergence points of water and land transportation modes, and are responsible for the task of cargo transportation transit. With the development of economic globalization and international trade, the functions of ports have been expanding and evolving.

Based on the examination and analysis of British ports,James Bird(1963) ${ }^{[1]}$ divided the development of ports into five stages based on the evolution of port infrastructure in time and space, namely, establishment, port expansion, hinterland expansion, specialization, and relocation out of urban areas or abandonment, which is the classic Anyport Model $\circ$ Taaffe E(1963) ${ }^{[2][3]}$ and others have drawn similar conclusions about the phasing of port development based on the analysis of the expansion of transport networks in developing countries. In 1971, Bird integrated the development of container technology into the Anyport model $^{[4]}$. After this,Hoyle $(1986)^{[5]}$ further refined Anyport

[1] Bird J H. The major seaports of the United Kingdom[M]. Hutchinson, 1963.

[2] Taaffe J, Morrill R L, Gould P R. Transport Expansion in Underdeveloped Countries: A Comparative Analysis[J]. Geographical Review, 1963, 53 503-52910.2307.

[3] Taaffe E J, Morrill R L, Gould P R. Transport expansion in underdeveloped countries: a comparative analysis[M]//Transport and development. Palgrave, London, 1973: 32-49.

[4] Bird J H. Seaports and seaport terminals[M]. Hutchinson, 1971. 


\section{Analysis of the stages of development and evolution of the characteristics of logistics in Gwadar port under the Background of China-Pakistan Economic Corridor and the Belt and Road}

model based on field research and studies of East African seaport. And Notteboom,(2005) based on the arbitrary port model, combined with the development of global economic integration and supply chain theory, divides the port development into four stages: "Setting - Expansion Specialization - Regionalization" ${ }^{\text {[6] }}$.

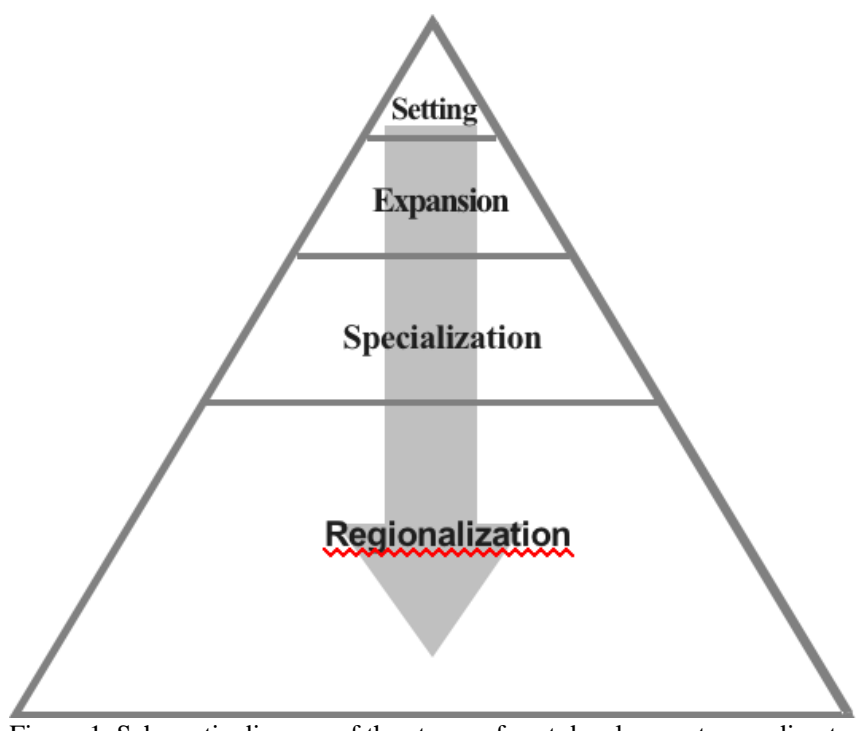

Figure 1. Schematic diagram of the stages of port development according to the model defined by Notteboom

Specifically, the Anyport model divides port development into four stages as follow :

During the setting stage, the ports were still in the primitive small port stage, with few connections between different ports, and the demand for maritime trade was still in the period of small quantity and short distance, when the ports mainly assumed the short-haul transportation of goods and simple ship maintenance work.

During the expansion stage, the port was in a rapid development stage, when the trade volume of the port grew rapidly. With the rapid development of shipping technology, inland transportation technology and terminal manufacturing technology, which led to the expansion of the economic hinterland of the port and the development of the industrial industry near the port, the port developed into a trade center with a part of industrial and commercial functions.

During the specialization stage, the port enter an initial stage of maturity. Due to further division of port handling functions and cargo storage technologies. The emergence of specialized terminal technologies such as container, ore, grain, etc., makes the port a comprehensive service center integrating transportation, industrial and commercial services and entertainment.

During the regionalization stage, the port enters a fully mature stage. Due to the improvement of the global supply chain system and the development of regional economies, homogenization between ports is serious and competition between different ports has shifted to the direction of regional

[5] Hoyle B S. Transport and economic development in the less-developed countries: Some reflections on the seaports of Kenya and Tanzania[J]. GeoJournal, 1986, 12(3): 233-242.

[6] Notteboom* T E, Rodrigue J P. Port regionalization: towards a new phase in port development[J]. Maritime Policy \& Management, 2005, 32(3): 297-313. economic development, with ports becoming an important link in the supply chain.

\subsection{Research on the Port Generations}

In 1992, the United Nations Conference on Trade and Development(UNCTAD) in the study "Port Development and Improvement of Modern Management and Organization Principles of Ports", divided ports into three generations according to their functions, Transport and Handling Center Transport and Commercial Center - Integrated Service Center.

With the development of supply chain management theorys, UNCTAD propose concept - the "fourth-generation port" . UNCTAD define the fourth grneration port as an organization physically separated but linked through common operators or through a common administration.

After that, $S$ á nchez and Wilmsmeier(2010)[ 7 ] supplemented and improved the port generations theory from the perspective of macro-influencing factors, and many Chinese scholars also argued and elaborated the port generations theory from various different perspectives.

According to the port generations theory, the development of the world's ports has gone through three generations, namely, the first generation of ports with traditional transportation, loading and unloading, and storage as the main functions; the second generation of ports with "transportation center + service center" as the main functions; and the third generation of ports with "international logistics center" as the main functions.

The first generation of ports was formed before the 1950s, and the main function was to handle, store and distribute maritime cargo. At this stage, the port was positioned as a transportation hub, and its main function was the transportation, storage and distribution of goods.

The second generation of ports emerged after the 1950s, in the main functions, in addition to cargo handling and warehousing, the port industry and various commercial trade activities were added, making the port a service center to provide various value-added services for goods. At this stage, the port is positioned as a logistics hub in the port city, and its main functions are not only transportation, but also distribution, processing and other value-added services.

The third generation of ports was created around the 1980 s, with the development of international trade and international logistics, as well as the rapid development of information technology, the port has developed rapidly on the basis of the original business, adding information services, technical support and other comprehensive value-added services, and the scope of the port has expanded again, including not only the traditional port area, but also the port-side industrial zone and logistics park. At this stage, the port is positioned as an international logistics hub, and the port is gradually developing in the direction of a modern integrated logistics center. In addition to shipping and industrial development, the main function of the port is to provide comprehensive and high value-added services for customers.

The fourth generation of ports is a concept that emerged in the early 21 st century. With the development and application

[7] Sánchez R J, Wilmsmeier G. Contextual port development: a theoretical approach[M]//Essays on port economics. Physica, Heidelberg, 2010: 19-44. 
of supply chain management theory, ports have become an important component of the supply chain. The function of the fourth-generation ports will go beyond transportation hubs, loading and unloading service centers and logistics centers, showing a change from "diversification" to "basing". At this stage, the port becomes an important link in the supply chain, and in addition to the functions of the first three generations of ports, it is more flexible and differentiated in terms of production and services, making it possible to seamlessly connect all links of the supply chain related to the port.

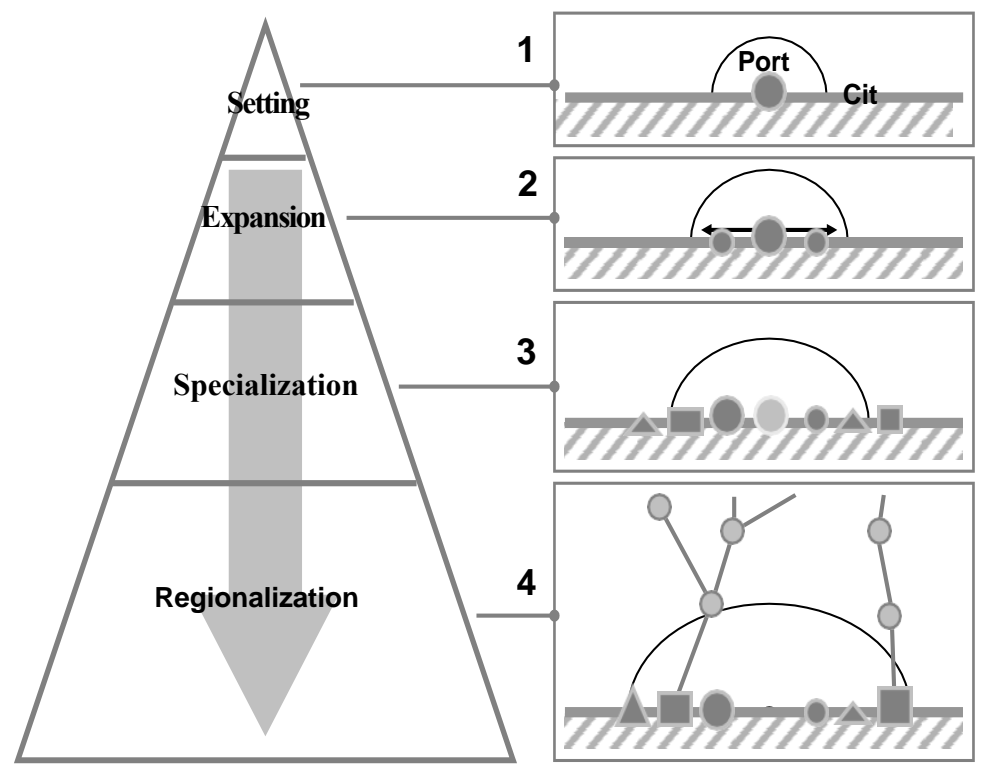

Figure 2. The stages of port development divided by the Port generations theory and Anyport model.[8]

\section{Research on the reasons for the evolution of port development}

Bird J H proposed and refined the Anyport model, which suggests that the main reason for the evolution of ports is the development of transportation technologies and transport network systems between ports and inland hinterlands. The upgrading and expansion of port terminals, the development of container transport technologies and the development of rail and road systems between ports and hinterlands are the main reasons for the evolution of ports.Based on their analysis of the relationship between ports and transport networks in developing countries, Taaffe et al. similarly suggest that the evolution of port development is due to the formation and development of transport networks between ports and hinterlands.In his study of the spatial layout of Australian ports and the characteristics of inter-port relations from 1861 to 1961 , Rimmer suggested that the evolution of ports was related to competition between neighboring ports, economic hinterland crossings, and cluster characteristics, and that competition for economic hinterland and logistics and transportation resources within the port system became a major reason for the continuous development of port

[8] ]Liu Guiyun, Zhen Hong, Zhao Dan. Study on the evolution mechanism of port function[J]. Zhejiang Journal, 2008, 2008(1): 183-186 functions. ${ }^{[9]}$ Notteboom believes that the evolution of port development is a requirement of global economic integration and regional economic development. The integration of global supply chains makes ports gradually become a transit node in the supply chain system, and the homogenization of port functions makes regional expansion and the increase of value-added services the main direction of port development. Therefore, the port gradually develops from a simple transportation node to a multifunctional service center.

Based on the UN's Intergenerational Port Model, Sánchez integrates the role of the physical environment, economic system, social environment and institutional policies on the port and proposes that when these four systems influence the port in a balanced way, the port will move to a higher stage according to the Intergenerational Port Model. The economic system, social environment and part of institutional policies are mainly influenced by global environmental factors, while the physical environment and another part of institutional policies depend mainly on regional environmental factors.

Leal considers port development as a process due to the interaction between three sets of variables: the first set of variables is the location advantage of the port, the second set of variables is the horizontal and vertical linkages between the port and related industries, and the third set of variables is the regulatory institutional framework of the port. These three groups of variables interact and promote each other in a circular manner, and together they promote the development of the port, while the absence of a single variable will lead to the lagging development of the port. The interconnections between port location, industry relationships, and institutional level drive the evolution of port development.

From the perspective of supply chain development and logistics distribution, Junwen Ma believes that the functions and development stages of ports are constantly transformed and upgraded with the development of the economy, and the overall performance shows the evolutionary trend of supply chain integration and the expansion of the scope and form of port logistics[10]。Sun Guangqi believes that the acceleration of economic globalization and regionalization process is the internal impetus for the continuous development of ports. From the early transportation hub interface and international economic and trade support platform, the port has developed to participate in the allocation of resources in the economic hinterland, and its role of integrated logistics and distribution has become increasingly obvious, and has become the central link between world and regional production, trade and consumption and has begun to become the main base for active planning and active participation in economic activities $^{[11]}$ 。 Xu Ping analyzed the reasons for the evolution of port development from the perspective of logistics development. She believes that the evolution of different development stages of ports is the result of the joint action of internal and external factors, namely, the development of the

[9] Rimmer P J. The search for spatial regularities in the development of Australian seaports 1861 - 1961/2[M]//Transport and development. Palgrave, London, 1973: 63-86.

[ 10] Ma Junwen. Port development stage analysis [J]. Journal of Hubei Correspondence University, 2013, 26(10): 75-76

[11]Sun Guangqi, Liu Yang. The development trend of modern ports and the new concept of "fourth generation ports" [J]. China Ports, 2005 (6): 16-17. 


\section{Analysis of the stages of development and evolution of the characteristics of logistics in Gwadar port under the Background of China-Pakistan Economic Corridor and the Belt and Road}

internal collection and distribution system and logistics information support system of ports, as well as the external international trade demand of ports, policy changes and the development of international supply chains. At the same time she believes that not all ports have to go through three levels of development, exhibit three development forms and finally become international ports, and that different ports do not go through the same development stages, development characteristics and final forms.[12]Zhen Hong also believes that the evolution of ports is the result of a combination of internal and external drivers, i.e., internal informationization of ports, improvement of supply chain systems, and institutional regulations and government policy support for ports, while inter-port competitive pressures and the diversity of market demand are the external drivers of port development.[13]

\section{ANALYSIS AND CONCLUSION}

\section{A. Briefing on Belt and Road and China-Pakistan Economic Corridor(CPEC) \\ 1.Briefing on the Belt and Road}

In September and October 2013, during visiting Central Asia and Southeast Asia, Chinese President Xi Jinping proposed the vision of building the Silk Road Economic Belt and the 21st-Century Maritime Silk Road to actively develop economic cooperation with countries along the route. The vision is to actively develop economic cooperation with countries along the route and jointly build a community of interests, destiny and responsibility with mutual political trust, economic integration and cultural tolerance. ${ }^{[14]}$

According to the "Belt and Road" plan, the whole framework can be divided into two parts: On land, the Initiative will focus on jointly building a new Eurasian Land Bridge and developing China-Mongolia-Russia, China-Central Asia-West Asia and China-Indochina Peninsula economic corridors by taking advantage of international transport routes, relying on core cities along the Belt and Road and using key economic industrial parks as cooperation platforms. At sea, the Initiative will focus on jointly building smooth, secure and efficient transport routes connecting major sea ports along the Belt and Road. The China-Pakistan Economic Corridor and the Bangladesh-China-India-Myanmar Economic Corridor are closely related to the Belt and Road Initiative, and therefore require closer cooperation and greater progress.

In terms of specific cooperation priorities, the "Belt and Road" plan is based on the resource endowments and economic complementarities of countries along the route, with policy communication, facility connectivity, smooth

[12] Xu P, Liu XL, Gao AY, Ma B, Luo K. Intrinsic development mechanism and case study of port logistics hubs[J]. Port Science and Technology,2016(03):6-12.

[13] Zhen Hong. The concept of fourth generation port and its implementation [J]. Journal of Transportation Engineering, 2005, 5(4): 90-95.

[14] Chen Jidong, Zhang Jianquan. The Positioning of China-Pakistan Economic Corridor in the Construction of "One Belt, One Road"[J]. Journal of Xinjiang Normal University (Philosophy and Social Science Edition),2016,37(04):125-133. trade, capital integration and people-to-people exchanges as the main content for in-depth cooperation ${ }^{[15]}$.

\section{Briefing on the plan of China-Pakistan Economic Corridor}

In May 2013, Chinese Premier Li Keqiang proposed the initiative of CPEC during his visit to Pakistan. He proposed to build an economic corridor with a total length of more than $3,000 \mathrm{~km}$ from Kashgar in China to Gwadar Port in Pakistan to boost connectivity between two neighbors. During President Xi Jinping's visit to Pakistan in April 2015, The two sides has set up the " $1+4$ " cooperation mode, namely, the two sides take CPEC as the core while prioritizing in Gwadar, Energy, Transport Infrastructure and Industrial Cooperation, which has opened a new chapter for the CPEC construction.China and Pakistan hope that through the construction of the China-Pakistan Economic Corridor, they can achieve win-win cooperation and common development, so that the China-Pakistan Economic Corridor can benefit the general public and become a major project with exemplary significance for regional connectivity construction. ${ }^{[16]}$

In November 2017, relevant ministries and departments of Chinese and Pakistan countries have set up a cooperation mechanism to coordinate the development of CPEC and jointly formulated the Long Term Plan for China-Pakistan Economic Corridor (2017-2030). And the Long Term Plan divide the cooperation between China and Pakistan into six key areas of cooperation: transportation and communication, energy, industry and trade, agriculture and regional poverty alleviation, tourism and non-government cooperation in the field of people's livelihood.And it also effectively match relevant national plans and local plans of China as well as Pakistan's Vision 2025.This plan is effective until 2030, the short-term projects included will be considered up to 2020; medium-term projects up to 2025; and long-term projects up to 2030 . The total planned investment is $\$ 46$ billion. ${ }^{[17]}$

The specific goals for the different periods are as follows :

By 2020, the CPEC strive to take the initial shape, major bottlenecks to Pakistan's economic and social development shall be basically addressed, and the CPEC shall start to boost the economic growth along it for both countries.

By 2025, the CPEC building strive to be basically done, the industrial system approximately complete, major economic functions brought into play in a holistic way, the people's livelihood along the CPEC signi $\square$ cantly improved, regional economic development more balanced, and all the goals of Vision 2025 achieved.

By 2030, the CPEC building strive to be entirely accomplished, the endogenous mechanism for sustainable economic growth in place, the CPEC's role in stimulating economic growth in Central Asia and South Asia brought into

\footnotetext{
${ }^{[15]}$ Vision and Actions on Jointly Building Silk Road Economic Belt and 21st-Century Maritime Silk Road", the "Belt and Road http://world.people.com.cn/n/2015/0328/c1002-26764633.html.

[16] Zhang Yaoming. The Construction of China-Pakistan Economic Corridor: Achievements, Risks and Countermeasures[J]. Journal of Northwestern University (Philosophy and Social Science Edition),2019,49(04):14-22.

[17] Zhang Yaoming. The Construction of China-Pakistan Economic Corridor: Achievements, Risks and Countermeasures[J]. Journal of Northwestern University (Philosophy and Social Science Edition),2019,49(04):14-22.
} 
holistic play, and South Asia shall grow into an international economic zone with global influence. ${ }^{[18]}$

\section{B. Briefing on Gwadar Port and its Positioning in the Belt and Road and China-Pakistan Economic Corridor \\ 1. Briefing on Gwadar Port}

Gwadar Port is a warm water port located in Pakistan's Balochistan Province. It is a deep seaport located on the Arabian Sea in Gwadar. Inspiration of Maritime Excellence, Gwadar Port is about $533 \mathrm{~km}$ from Karachi and $120 \mathrm{~km}$ from the Iranian border and $380 \mathrm{~km}$ northeast of Oman across the Arabian Sea. Geographically, the port is situated just $400 \mathrm{~km}$ from the strategic Hormuz Strait, which carries 40 percent of Chinese imported oil from Gulf countries. and is the connection point between the oil-producing areas of the Middle East and the densely populated areas of South Asia.Due to poor operations and various other reasons, the Port of Singapore Authority transferred the operation of Gwadar Port to China Overseas Port Holding Co Ltd. in 2013 After 2013, COPHC upgraded and expanded the existing port infrastructure and warehouses based on the first phase of construction, and gradually advanced the second phase of port infrastructure construction with the goal of building more than 9 new multi-purpose berths and bulk commodity transportation storage facilities. ${ }^{[19]}$

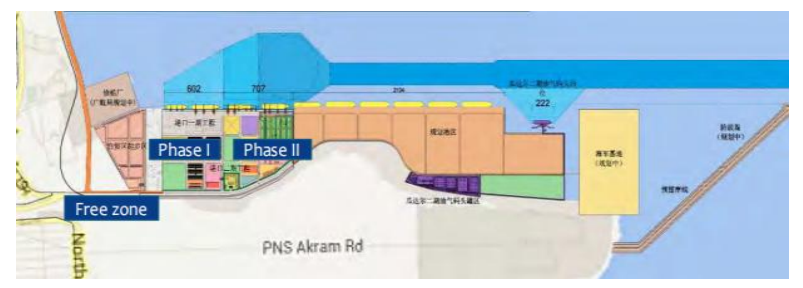

Figure 3. Gwadar Port Construction Plan

\section{Gwadar's Positioning in the Belt and Road and} China-Pakistan Economic Corridor

\subsection{Gwadar's Positioning in the Belt and Road}

According to the specific content of the "Vision and Actions on Jointly Silk Road ",the "Belt and Road " will build a number of model economic corridors with countries along the route on the basis of the international countries and many ports" structure of the layout ${ }^{[20]}$. "Six corridors" refers to six international economic cooperation corridors, including the New Asia-Europe Continental Bridge, China-Mongolia-Russia, China-Central Asia-West Asia, China-Central South Asia, China-Pakistan and Bangladesh-China-India-Myanmar economic corridors; "six roads" refers to railroads, highways, shipping, aviation, pipelines and spatial integrated information networks, which are the main elements of infrastructure interconnection; "multi-country" refers to a number of early cooperation countries; "multi-port" refers to a number of cooperation

[ 18 ] Hilali A Z. China-Pakistan Economic Corridor (CPEC): A MultiDimensional Plan 2017-2030 and Its Characteristics[J]. South Asian Studies, 2020, 34(2).

${ }^{[19]}$ Qi Guanjun. Gwadar Port[J]. China Investment (English and Chinese), 2020, 1 .

${ }^{[20]}$ A chart to understand the "six corridors and six roads, many countries and many ports"[J]. China Ocean Shipping,2019(05):12. ports to ensure the safe and smooth flow of the sea transport corridor.

Gwadar Port is located at the intersection of the western land starting point of the Belt and Road China-Pakistan Economic Corridor (CPEC) and the important sea port node of the Belt and Road. The CPEC runs from Kashgar, China to Gwadar Port, Pakistan, extending the New Silk Road southward to the Indian Ocean and connecting the "One Belt" with the "One Road". Once completed, it will connect the Asia-Europe Continental Bridge in the north and the Maritime Silk Road in the south, becoming an important node connecting the land and maritime Silk Road.

In short, the "One Belt, One Road" leads to the world by land and sea respectively, and there are not many nodes where the two can intersect, but from the current situation, the most qualified and possible one is Gwadar Port. It connects the "Silk Road Economic Belt" and the "21st Century Maritime Silk Road", which can maximize the overall benefits of the "Belt and Road" and make "The Gwadar Port plays the role of a bridge and a hub connecting the two, and has an irreplaceable position.

2.2. Gwadar's Positioning in the China-Pakistan Economic Corridor

According to the "Long Term Plan for China-Pakistan Economic Corridor Vision (2017-2030)", the overall plan of China-Pakistan Economic Corridor is "one belt, three axes, multiple channels" and "five key functional areas" of the spatial layout, and the comprehensiveTransportation system is the focus of the construction of China-Pakistan Economic Corridor. According to the project implementation information on the official website of China-Pakistan Economic Corridor, there are currently 70 projects in China-Pakistan Economic Corridor, of which 26 are transportation infrastructure projects, which can be broadly divided into four types : ports and supporting facilities, aviation, highways and rail transportation. ${ }^{\text {[21] }}$

In the specific project promotion since 2015, the Pakistani government has been ensuring that the western route of the "East, Central and West" route is the first to advance. According to statistics, road transport projects in the Western route account for $75 \%$ of the total number of road projects. ${ }^{[22]}$ The Gwadar port is the starting point of the western transportation line and the focus of construction, and is also the key project of the construction of China-Pakistan Economic Corridor. As a key construction area of China-Pakistan Economic Corridor, Gwadar Port not only includes a series of comprehensive transportation projects including regional road connection, perfect support of Gwadar Port and new Gwadar International Airport, but also undertakes several other projects in key areas of cooperation between China and Pakistan, such as Develpment of Free Zone, China-Pakistan Friendship Hospital and China-Pakistan Gwadar Faqeer Primary School. Gwadar Port is becoming a new engine to promote the construction of China-Pakistan Economic Corridor and the development of Pakistan.

[21] Li Q, Luo C. Lei. Analysis of the progress of construction of transportation system in China-Pakistan economic corridor[J]. Transportation Enterprise Management,2020,35(04):20-24.

[22] Li Q, Luo C. Lei. Analysis of the progress of construction of transportation system in China-Pakistan economic corridor[J]. Transportation Enterprise Management,2020,35(04):20-24. 


\section{Analysis of the stages of development and evolution of the characteristics of logistics in Gwadar port under the Background of China-Pakistan Economic Corridor and the Belt and Road}

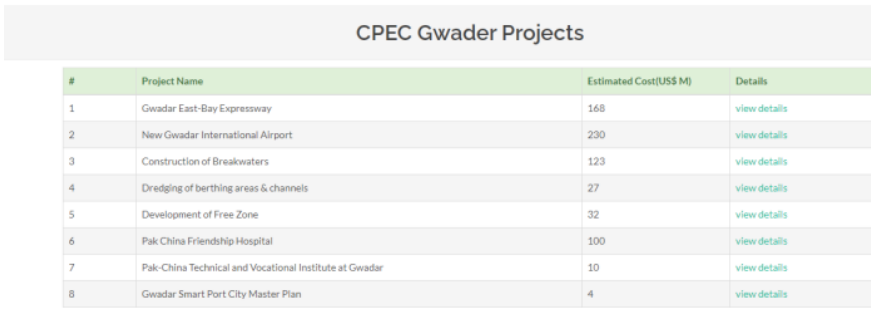

Figure 4. Projects under construction in Gwadar Port

\section{Analysis of the stages and evolutionary features of logistics development in Gwadar port and its dynamics 1. The stages and evolutionary features of logistics development in Gwadar port}

Taking into account the geographical location of Gwadar port and the background of China-Pakistan Economic Corridor and "One Belt, One Road" construction, its logistics development can be divided into the following three stages: transportation center stage (2015-2020), regional logistics hub stage (2021-2030) and international logistics hub stage (2031-)

\subsection{Stage I (2015-2020) - Transportation Center Stage}

This is the stage of accelerated transformation of Gwadar Port into a modern logistics port. The focus is on building the main advantages of logistics development, developing and improving the port business with a focus on minerals based on the superior geographical position of Gwadar port. We will strive to develop the port into a regional entrepot, an important import and export base in Central Asia, and a transit base for grain and ore on the Persian Gulf coast. Laying the foundation for the construction of a modern logistics hub port.

At this stage, the development of Gwadar port is mainly characterized by the improvement of the efficiency of port logistics operations and productivity. Through the application of intelligent technologies and management models, the overall and single operation efficiency of the port infrastructure will be improved, the efficiency of loading and unloading operations and port logistics services will be improved, and the goal of efficient and safe port logistics will be achieved.

\subsection{Stage 2 (2021 - 2030) - Regional Logistics Hub Stage}

This stage is the basic formation period of the modernized port of Gwadar. Gwadar Port will focus on improving port information and intelligence construction and modernizing port functions by combining with the development of port industries. Moreover, through the connection with other transportation projects in the China-Pakistan Economic Corridor, Gwadar Port will expand its economic hinterland, improve its transportation system, and develop into an important energy transportation base in South Asia, and become a large-scale, modernized and comprehensive service port.

The development of Gwadar Port at this stage is characterized by the integration of national policy support and urban planning layout, becoming a connection point between the port logistics system and the urban logistics system. The initial integration of the port and the city will be achieved through the development of industrial industries, the concentration of commerce and trade, the concentration of logistics parks, the construction of a bonded logistics system, and the establishment of a logistics information platform, making it a regional platform for the concentration of logistics elements and services.

\subsection{Stage 3 (2031 - ) - International Logistics Hub Stage}

This is the stage of adjustment and improvement of the Gwadar port for the construction of a modern port. Gwadar Port will continue to promote the development of port industries as an important regional transit and distribution base as well as an important energy transportation base in South Asia, highlighting the leading effect of the port on the economic development of the city and the region, and creating a modern port with logistics, information flow and capital flow.

Through the construction of the port collection and distribution system and the improvement of the surrounding traffic conditions, Gwadar Port will become the hub of the regional port cluster and the international logistics system, connecting the maritime economy and the land economy, becoming an important carrier of regional and global integration, attracting manufacturing and service industries to gather, generating various supporting industries and high-end value-added services such as finance, maritime and insurance, and forming a complete logistics supply chain and industrial chain.

At the same time, in this stage, the port logistics of Gwadar Port plays a prominent role in the supply chain, occupies a more important position in the high-end logistics industry, and has become a special and very important platform for supply chain management with more obvious security and green development goals.

\section{Analysis of the dynamics of logistics development in Gwadar port}

According to the analysis of scholars on the evolution of port development system and the development background of Gwadar port itself, we can divide the overall logistics development dynamics of Gwadar port into two aspects, namely, external and internal drivers. The external driving force - the development trend of the world ports, the government policy support, and the requirements of the customers' transportation goods; the internal driving force the port's demand for survival and development, and the development of the port supply chain.

2.1. The external driving force

2.1.1. The impact of the development trend of the world's ports

The functions of ports in today's world has been changed dramatically compared with the third generation of ports in the 1980s, especially when supply chain management is maturing, the role of ports in the supply chain is also changing dramatically. And the modern ports have shown the development trend of cooperation, regionalization, leaning, effective and greening.As a modern port jointly built by Pakistan and the Chinese government, the logistics development of Gwadar Port, which is a modern port, is bound to be influenced by the development trend of ports in the world today.

\subsubsection{Government \& Policy Support}

The Gwadar Port, due to its special geographical location and natural deep-water harbor, plays an important role in the "Belt and Road" and China-Pakistan Economic Corridor plans, and has received key support from the government 
2016, the Pakistani government enacted the annual Finance Act to formally implement the 23-year tax exemption for the Gwadar Port Free Zone, and the government encourages private enterprises to build recreational facilities and leisure resorts in the Gwadar Port area. The government has encouraged private enterprises to build recreational facilities and leisure resorts in the coastal areas of Gwadar port. In order to simplify the administrative means to support the free trade of importers and exporters in the Gwadar region, the Pakistani government established the Gwadar Development Authority (GDA), which has full authority to handle the development of Gwadar, to avoid the negative impact of the complicated and slow administrative efficiency on the development of Gwadar port. Other policies such as $100 \%$ foreign ownership of Gwadar Free Zone, 99-year lease, 100\% profit recovery, flexible visa policy, etc., and the Chinese government has been encouraging Chinese companies and individuals to invest and build in Gwadar Port with certain preferential treatment, are the external drivers for the development of Gwadar Port logistics.

\subsubsection{Customer requirements for transporting goods}

The Balochistan region, where Gwadar port is located, is rich in mineral resources and natural gas resources, and is a famous resource province of Pakistan. The mineral resources mainly include coal, copper, iron, lead, zinc, chromium, manganese, marble, sulfur, gypsum, barite, etc., which account for about $50 \%$ of the total mineral resources of the country, as well as Sui oil field, which is one of the ten largest natural gas fields in the world. Moreover, the fishery resources near Gwadar port are relatively rich, producing high quality seafood, of which about $40 \%$ are transported through Karachi port to Sri Lanka, South Korea, China and Hong Kong for sale, which is an important local trade activity. The Strait of Hormuz, which is adjacent to Gwadar port, is an important oil transportation route, and Iran is a major exporter of oil resources in the world. From the point of view of trade products in Gwadar port, cargo owners generally have the characteristics of large and stable volume and fixed routes, and such commodity transportation pay more attention to the quality and timeliness of services provided by the port, hoping that the port can help them reduce operating costs. Some of the larger shipping companies or cargo owners have a strong incentive to invest in logistics facilities with the port or cooperate with the port to form a joint venture in order to reduce their operating costs, which is one of the important driving forces for the development of port logistics in Gwadar.

\subsection{The internal driving force}

\subsubsection{The need for the port to survive and grow}

From the perspective of Gwadar port itself, for its own survival and development is an internal driver for the development of port logistics in Gwadar port. There are three major ports in Pakistan, Karachi Port, Port Qasim and Gwadar Port, and the annual cargo throughput of Karachi Port and Port Qasim was 43.42 million tons and 30.01 million tons respectively in 2015, accounting for 95\% of Pakistan's international cargo volume. Gwadar port is currently mainly used to deliver government-designated cargoes such as wheat, fertilizers, fishery products, etc. as well as to undertake a small portion of transit trade from other countries, with limited throughput and an annual throughput of around 1 million tons. On the one hand, Gwadar port has a small cargo source, single goods, and the infrastructure is not perfect compared to the other two ports, and there is a relative lack of professional handling and transportation personnel and equipment, so Gwadar port does not have any advantage in the face of competition from the two major domestic ports. Therefore, the survival and development in the competition of Pakistan's domestic ports is one of the internal drivers of Gwadar Port's logistics development.

\subsubsection{The development of port supply chain}

The improvement of the Gwadar port's transportation system and the development of transportation facilities between the port and the economic hinterland have made Gwadar port a driving point for regional development, playing the role of a logistics center and an industrial center near the port, and its development will be linked to the changes in the regional economy. In particular, under the "One Belt, One Road" and China-Pakistan Economic Corridor (CPEC) overall transport corridor layout, Gwadar Port has not only the port and supporting infrastructure construction, but also the Pakistan Western Highway Traffic (Islamabad - Burhan - Dera Ismail Khan - Quetta - Soraba Gwadar) project, the China-Pakistan Railway project and the new Gwadar International Airport project is under construction. Through the construction of a comprehensive transportation system, the future Gwadar port will not only become China's access to the Indian Ocean, but will also open up access to the Middle East and the Caspian Sea for the transportation of oil and gas resources, enabling China to connect directly with the oil exporting countries in West Asia. ${ }^{[23]}$; It will also greatly shorten the voyage between the five Central Asian countries and Africa and Europe, and will deliver goods directly to Central Asia and Xinjiang region of China via Uthal, Khuzd $\bar{a} r$ and Sukur ${ }^{[24]}$, forming a vast economic hinterland.

With the development of Gwadar port's transportation system and transportation facilities between the port and the economic hinterland, Gwadar port will gradually transform from a mere transportation center into an integrated service link in the supply chain, which is an internal force for the development of logistics in Gwadar port.

\section{REFERENCES}

[1]Cheng,Yunjie, Li,Qiaoming.Risk Identification and Control of China-Pakistan Economic Corridor Construction [J].North China Business,2020(08):19-23.

[2]Chen Jing, Sun Xiangjun, Dai Xiaoqing, Yang Bo. Prospects of transportation development in node cities of "One Belt and One Road"[J]. Science and Technology Herald,2020,38(14):102-108.

[3]Wang Dandan. Policy Recommendations for Promoting the Construction of Gwadar Port with High Standards[J]. China Ports,2020(07):12-15.

[4]Huang Zongzhi. China's New Comprehensive Vision and Forward-Looking Vision: The Belt and Road Initiative and the ADB[J]. Academic Monthly,2020,52(07):93-104.

[5]Li Q, Luo C. Lei. Analysis of the progress of construction of transportation system in China-Pakistan Economic Corridor[J]. Transportation Enterprise Management,2020,35(04):20-24.

[23] Takrim K, Afeef M. Prospects of Gwadar Port as a Hub Port[J] Journal of Managerial Sciences, 2015, 9(1).

${ }^{[24]}$ Li Jianjun, Sun Hui. The construction of China-Pakistan economic corridor in the context of "One Belt and One Road": realistic basis and path selection[J]. Journal of Xinjiang University (Philosophy - Humanities and Social Sciences Edition),2017,45(01):1-9. 


\section{Analysis of the stages of development and evolution of the characteristics of logistics in Gwadar port under the Background of China-Pakistan Economic Corridor and the Belt and Road}

[6]Liu Changjian. Improving Overseas Port Network and Promoting the Construction of "One Belt, One Road" [J]. Science and Technology Herald,2020,38(09):89-96.

[7] Khetran M S. The potential and prospects of Gwadar Port[J]. Strategic Studies, 2014, 34: 70-89.

[8]Takrim K, Afeef M. Prospects of Gwadar Port as a Hub Port[J]. Journal of Managerial Sciences, 2015, 9(1).

[9]Shahzad S M. Gwadar Port Growing Beyond Economic Glory[J]. Int. J. of Multidisciplinary and Current research, 2019, 7.

[10]Khan S A. Geo-economic imperatives of Gwadar Sea Port and Kashgar economic zone for Pakistan and China[J]. IPRI Journal, 2013, 13(2): 87-100.

[11]Naz A, Ali F. Gwadar port: as an economic hub for Maritime trade in the world corridor (CPEC)[J]. Journal of Business and Social Review in Emerging Economies, 2018, 4(1): 7-16.

[12]Yang Ximing, Gao Zhigang. The concept of China-Pakistan Economic Corridor Free Trade Port (Gwadar Port)[J]. Macroeconomic Management,2019(09):76-83.

[13]Zhou Jinghui, Xi Fang, Li Yu. Study on the development and layout of Gwadar Port[J]. Water Transport Engineering,2019(09):125-128+154.

[14]Lei Yanling,Liu Chongxian. Analysis of China-Pakistan Logistics Corridor Construction[J]. Foreign trade and economic cooperation, 2019(06):6-9.

[15]Yang Fanxin. Facility connectivity: the cornerstone of the sustainable development of "One Belt, One Road" $[\mathrm{J}]$. Global Business Classics,2019(05):40-45.

[16]Zhang Hui. China-Pakistan Economic Corridor: A model of "One Belt One Road" construction[J]. China Today,2019,68(05):23-25.

[17]Zhang Yaoming. The Construction of China-Pakistan Economic Corridor: Achievements, Risks and Countermeasures[J]. Journal of Northwestern University (Philosophy and Social Science Edition),2019,49(04):14-22.

[18]Hilali A Z. China-Pakistan Economic Corridor (CPEC): A MultiDimensional Plan 2017-2030 and Its Characteristics[J]. South Asian Studies, 2020, 34(2).

[19]Song Wei. Achievements and challenges of "One Belt, One Road" construction[J]. Leadership Science Forum,2019(08):46-56.

[20]Lv Guoqing. Typical port logistics development models at home and abroad for the reference of ports in coastal late-developing regions[J] Logistics Technology,2018,37(08):19-24.

[21]Zhang Yuan. Assessment of Gwadar Port Construction in the Framework of China-Pakistan Economic Corridor[J]. China International Strategic Review,2017(00):139-147.

[22]Li Jianjun, Sun Hui. Construction of China-Pakistan Economic Corridor in the Context of "One Belt, One Road": Realistic Basis and Path Choice[J]. Journal of Xinjiang University (Philosophy - Humanities and Social Sciences),2017,45(01):1-9

[23]Chen Lijun. "One Belt, One Road" and the Construction of China-Pakistan Economic Corridor[J]. Contemporary World,2017(01):54-57.

[24]Iftikhar M N, Xie L, Shakeel K, et al. The institutional and urban design of Gwadar City[J]. International Growth Centre IGC, 2019.

[25]Zhang Liwei. Foundations and Challenges of China-Pakistan Economic Corridor Construction in the Context of "One Belt, One Road" Strategy[J]. Reform and Strategy,2016,32(10):160-164.

[26]Liu Zongyi. Construction of China-Pakistan Economic Corridor: Progress and Challenges[J]. International Studies,2016(03):122-136+138.

[27]Chen Jidong, Zhang Jianquan. The Positioning of China-Pakistan Economic Corridor in the Construction of "One Belt, One Road" $[\mathrm{J}]$ Journal of Xinjiang Normal University (Philosophy and Social Science Edition),2016,37(04):125-133

[28]Xu P, Liu XL, Gao AY, Ma B, Luo K. Intrinsic development mechanism and case study of port logistics hubs[J]. Port Science and Technology,2016(03):6-12.

[29]Zhang Xiping. Study on the Establishment of Logistics Trade Corridor in the Framework of China-Pakistan Economic Corridor - China-Pakistan Logistics Trade Corridor with Kashgar as the Hub Center[J]. Financial Development Review,2015(10):99-105.

[30]Song Yaohui, Xia Yong, Su Yang. Discussion on the construction of "China-Pakistan Economic Corridor" under "One Belt and One Road" strategy[J]. Foreign Economic and Trade Practice,2015(10):27-30.

[31]Yang Hang. The impact of Gwadar port development on "One Belt, One Road" strategy[J]. Development Research,2015(09):19-23.

[32]Zhang Bing. Analysis of typical port logistics development model and inspiration for China's port logistics development[J]. Logistics Technology,2015,34(12):52-54.

[33]National Development and Reform Commission, Ministry of Foreign Affairs, Ministry of Commerce. Vision and Action for Promoting the
Construction of the Silk Road Economic Belt and the 21st Century Maritime Silk Road[N]. People's Daily,2015-03-29(004).

[34]Wang Changjiang. Analysis and inspiration of typical port logistics development models in the world[J]. Economic and social system comparison,2012(01):218-223.

[35]Huang Zhi. Research on the integration of port information platform based on SOA [D]. Shanghai Jiaotong University,2008.

[36]Si Yintao, Ji Shouwen, Ma Jihui. Research on the development of port city logistics[J]. Logistics Technology,2007(06):27-28

[37]Li M., Zhang W. Shenzhen Port Logistics Development Experience[J]. Jiangsu Urban Planning,2006(10):31-35.

[38]Zhang, L.A., Feng, K.C.. The development and inspiration of typical port logistics at home and abroad[J]. China Logistics and Purchasing,2004(10):16-20.

[39]Zeng Jia, Jin Qiao, Shen Jinsheng. The inspiration of foreign port logistics development to Lianyungang port logistics development[J]. Journal of Beijing Jiaotong University (Social Science Edition), 2007(04):34-37

[40]Li Xegong, Ren Wei. Trends, characteristics and inspiration of foreign port logistics development[J]. Port Technology,2007(02):3-6+10.

[41]Bird J H. The major seaports of the United Kingdom[M]. Hutchinson, 1963.

[42]Taaffe J, Morrill R L, Gould P R. Transport Expansion in Underdeveloped Countries: A Comparative Analysis[J]. Geographical Review, 1963, 53: 503-52910.2307.

[43] Taaffe E J, Morrill R L, Gould P R. Transport expansion in underdeveloped countries: a comparative analysis[M]//Transport and development. Palgrave, London, 1973: 32-49.

[44] Bird J H. Seaports and seaport terminals[M]. Hutchinson, 1971.

[45]Hoyle B S. Transport and economic development in the less-developed countries: Some reflections on the seaports of Kenya and Tanzania[J]. GeoJournal, 1986, 12(3): 233-242.

[46] Notteboom* T E, Rodrigue J P. Port regionalization: towards a new phase in port development[J]. Maritime Policy \& Management, 2005 32(3): 297-313

[47]Sánchez R J, Wilmsmeier G. Contextual port development: a theoretical approach[M]//Essays on port economics. Physica, Heidelberg, 2010 $19-44$

[48]Rimmer P J. The search for spatial regularities in the development of Australian seaports 1861-1961/2[M]//Transport and development. Palgrave, London, 1973: 63-86.

[49]Ma Junwen. Port development stage analysis [J]. Journal of Hubei Correspondence University, 2013, 26(10): 75-76.

[50]Sun Guangqi, Liu Yang. The development trend of modern ports and the new concept of "fourth generation ports" [J]. China Ports, 2005 (6): 16-17.

[51]Liu Guiyun, Zhen Hong, Zhao Dan. Study on the evolution mechanism of port function[J]. Zhejiang Journal, 2008, 2008(1): 183-186.

[52]Zhen Hong. The concept of fourth generation port and its implementation [J]. Journal of Transportation Engineering, 2005, 5(4): 90-95.

[53]Yang Jinglei, Wang Yu. Port development model based on the perspective of specialized division of labor[J]. Port Economics, 2012, 1: 14-18.

[54]Xifang, Zhan Meng. Analysis of the evolution and trends of Mexico's port development[J]. China Ocean Shipping,2018(10):62-64

[55]He Lin,Chen Yan,Hu Songjun,Sun Hui. The concept and characteristics of the fourth generation port[J]. Water Transport Engineering,2011(06):49-53.

[56]An Xiaopeng, Han Zenglin. The advent of integrated logistics era and the evolution of port functions[J]. Tropical Geography,2001(03):276-281.

[57]Zhang He, Zhen Hong. Study on the driving forces leading the evolution of third-generation ports to fourth-generation ports $[\mathrm{J}]$. China Ports,2009(06):14-15.

Deng Aimin, Ph.D., Professor of School of Economics and Trade, Hunan University, Ph.D. Supervisor, Director of the Institute of Transportation and Logistics, Hunan University; the first batch of scholars of the Hundred Talents Project of Hunan Province, Director of the Expert Committee / Vice President of Hunan Modern Logistics Society,Expert in the evaluation of master's and doctoral dissertations in the degree center of the Ministry of Education, and expert in reviewing the National Social Science Fund.

Tiancheng $\mathrm{Xu}$, Master of School of Economics and Trade , Hunan University; Major in Industrial Economics, the research direction is logistics and supply chain management. 